\title{
THE EQUITY OF ANTENATAL CARE STANDARD IN DIFFERENT AGES
}

\author{
Standar Ekuitas Pelayanan Antenatal pada Berbagai Usia \\ *Efvina Goemawati ${ }^{1,}$ Titis Widya Kristy ${ }^{2}$ \\ ${ }^{1}$ Faculty of Public Health, Universitas Airlangga, Indonesia \\ 2Persakmi Jatim, Indonesia \\ ${ }^{*}$ Correspondence: efvinagoemawati@gmail.com
}

\begin{abstract}
Background: Antenatal care standard ensures the health of pregnant woman with early detection of risk factors, prevention and treatment provided by competent health practitioners. Health equality does not always mean improving the same service for everyone, but the services are provided according to everyone's needs.

Aim: This research was to examine the antenatal standards based on patients' needs in the Public Health Centre of Medokan Ayu.

Methods: This research was observational by using cross-sectional design. The population in this study was 518 pregnant women who gave birth from June 2011 to May 2012 in the Primary Healthcare Center of Medokan Ayu. There were 88 mothers as samples obtained by a cluster random sampling.

Results: This study determines the need for antenatal care standards can be fulfilled more for the age of $<20$ years and $>30$ years to avoid the high risk of maternal death and needs and equity based on the standards. There were no differences in the acceptance standard of antenatal care (5T and 7T) based on the age group between $<20$ years, $20-30$ years, and $>30$ years.

Conclusions: Reproductive women need to recognize the importance of antenatal care. The availability and quality of antenatal care need to be further maintained by the healthcare providers, and they need to be more aware to the importance of antenatal care. Women in later reproductive period need to be aware of the prevailing risks in circumstances.
\end{abstract}

Keywords: Equity, Antenatal care standard, Age.

\section{ABSTRAK}

Latar Belakang: Standar pelayanan antenatal bertujuan untuk menjamin perlindungan kepada ibu hamil, berupa deteksi dini faktor risiko, pencegahan dan penanganan komplikasi yang diberikan oleh tenaga kesehatan yang berkompeten. Ekuitas dalam kesehatan tidak selalu mendistribusikan pelayanan yang sama kepada setiap orang,namun pelayanan diberikan sesuai dengan kebutuhan setiap orang.

Tujuan: Tujuan dari penelitian ini adalah untuk menganalisis ekuitas standar pemeriksaaan antenatal berdasarkan karakteristik usia ibu di wilayah kerja Puskesmas Medokan Ayu.

Metode: Penelitian ini merupakan penelitian survei dengan desain observasional. Rancang bangun dari penelitian ini adalah cross sectional. Populasi pada penelitian ini adalah lbu hamil di wilayah kerja Puskesmas Medokan Ayu yang melahirkan pada Bulan Juni 2011 s.d. Mei 2012 sebanyak 518 ibu dengan perhitungan sampel yang diperoleh dengan cluster random sampling sebanyak $88 \mathrm{ibu}$.

Hasil: Penelitian ini menentukan kebutuhan akan standar perawatan antenatal lebih dapat dipenuhi untuk usia <20 tahun dan >30 tahun untuk menghindari risiko tinggi kematian ibu dan kebutuhan serta pemerataan berdasarkan standar. Tidak ada perbedaan dalam standar penerimaan layanan antenatal (5T dan 7T) berdasarkan kelompok usia antara <20 tahun, 20-30 tahun, dan> 30 tahun.

Kesimpulan: Wanita usia reproduksi perlu menyadari pentingnya menerima pelayanan antenatal. Ketersediaan dan kualitas layanan perawatan antenatal perlu diperkuat lebih lanjut pada pelayanan kesehatan dan lebih banyak kesadaran mengenai pentingnya standar pelayanan antenatal. Wanita di tahun-tahun berikutnya dari periode reproduksi mereka perlu dibuat sadar akan risiko yang berlaku untuk keadaan yang dialami.

Kata Kunci: Ekuitas, Standar pelayanan antenatal, Usia.

\section{INTRODUCTION}

The antenatal cares are kind of health services provided to pregnant women during their pregnancy based on the antenatal care standard. The principle of antenatal care is to provide services or assistance to improve maternal health in pursuing family health. Maternal mortality in Indonesia reached up to 126 per 100,000 live births in 2015 . The phenomena showed that maternal mortality in Indonesia was still high, and it had not fulfilled the target of SDGs (Sustainable Development Goals) 
that target 70 per 100,000 live births (World Health Organization, 2015). Maternal and infant mortality rate are two indicators for the quality of healthcare facilities. The quality of healthcare facilities includes the accessible health services.

The aim of the antenatal care is to ensure the protection for pregnant women by implementing early detection of risk factor, preventing and handling complications by health professionals. Antenatal cares according to the standards should be performed by health professionals with a frequency of visits at least four times. It is expected that the implementation of complying antenatal care can reduce Maternal Mortality Rate (MMR) and Infant Mortality Rate (IMR) in accordance with the targets of Sustainable Development Goals (SDG's) in health.

Health equity does not mean always providing the same service to everyone, rather fitting the services to individual needs. Although the population's life expectancy in average has increased significantly, the inequality of health status must be considered. The availability of maternal health services needs to be an important concern regarding the birth mortality as an indicator of health status other than the Infant Mortality Rate. Based on the IDHS, linear regression predictions for maternal mortality in 2015 were 161 per 1000 live births and did not meet the 2015 MDG target of 102 per 1000 live births. In order to achieve this, a strong effort is needed to reduce maternal mortality in Indonesia, such as antenatal care as the second pillar of safe motherhood.

Based on the data obtained from the Primary Healthcare Center of Medokan Ayu, the first average attendance had met the target set by Surabaya District Health Office above 95\%. The fourth attendance of antenatal care in the Primary Healthcare Center of Medokan Ayu was still less than $90 \%$ for the past 4 years and had not reached the targets set by Surabaya District Health Office. It shows that the antenatal visit is not complete while the antenatal care requirement is a minimum of four visits during pregnancy. Decrease of antenatal care coverage from the first visit to the fourth visit was more than $5 \%$ in the Primary Healthcare Center of Medokan Ayu from 2008 to 2011. This study aimed to analyse the equity standard of antenatal care based on the characteristics of maternal age in the Primary Healthcare Center of Medokan Ayu.

\section{METHOD}

This research carried a survey. In the survey, all objects or populations cannot be examined, but only a part of the population (samples) are chosen. This research was observational analytical research with a cross-sectional study. The population of this study was 518 pregnant women who gave birth in June 2011 to May 2012 in the Primary Healthcare Center of Medokan Ayu.

The minimal sample was 82 mothers, and the sampling technique used was probability sampling with a cluster random sampling. The study was conducted in the Primary Healthcare Center of Medokan Ayu, located in Medokan Ayu Village (Community Unit II, X, XIII), Penjaringan Sari Village
(Community Unit I, VI, X), and Wonorejo Village (Community Unit I, II, X).

The community units were selected to measure the equity in the community. It was known that the total sample from each community unit was 88 mothers. In Medokan Ayu Village, Community Unit II invited 20 mothers, Community Unit X invited as many as 6 mothers, and Community Unit XIII asked 11 respondents. Whereas, in Penjaringan Sari Village, Community Unit I invited 12 mothers, Community Unit $\mathrm{VI}$ asked 6 mothers to participate, and Community Unit $X$ invited 10 mothers. In Wonorejo Village, Community Unit I asked 10 mothers, Community Unit II involved 6 mothers and Community Unit $X$ invited 7 mothers. Overall sample for this research was 88 mothers.

The independent variables in this study were individual factors (pregnant women), demographic factors, namely maternal age and dependent equity standard of antenatal care. The instrument used to collect data was questionnaires. Primary data were obtained with interview and guided questionnaires, Meanwhile, the secondary data come from data or documents on the number of pregnant women, the target number of pregnant women, and the number of Community Unit in each village of Primary Healthcare Center of Medokan Ayu.

\section{RESULTS AND DISCUSSION}

High-risk pregnant women were usually at a young age ( $<20$ years) or too old age ( $>30$ years). This condition affected the use of antenatal cares and needs during pregnancy.

Table 1. Characteristics of pregnant women based on age in the Primary Healthcare Center of Medokan Ayu.

\begin{tabular}{ccc}
\hline Age & $\mathbf{f}$ & $\%$ \\
\hline$<20$ years & 3 & 3.41 \\
$20-30$ years & 57 & 64.77 \\
$>30$ years & 28 & 31.82 \\
\hline Total & 88 & 100
\end{tabular}

Table 1 shows that most of respondents in the Primary Healthcare Center of Medokan Ayu were pregnant at the age of 20 until $30(64.77 \%)$, and the rest were pregnant at the age of $<20$ years $(3.41 \%)$. These data explain that pregnant women in this study were still at the limits of reproductive health. Safe ages of pregnancy and childbirth occur at the age of 20 until 30 years. Maternal mortality and labouring women under 20 years old were 2-5 times higher than maternal immortality that occurred at the age of 20-29 and after 30-35 years.

Based on that, the needs of pregnant women should be more fulfilled by the ages of $<20$ and $>30$ years. The reasons are because the ages of $<20$ and $>30$ have a higher risk of maternal immortality than the ages of $20-30$ years. The maternal mortality at the age of 15-19 was lower, but then it increased for above 25-year-old pregnant women and was substantially higher than the other two groups above 30-year-old or more than 4-year-old pregnant women (Blanc, Winfrey and Ross, 2013).

A person in the late stage of being adolescence has a high awareness to seek care 
when they need it (Kapoyos, 2015). Pregnant women between the ages of 20-30 years will have a mature reproduction to receive pregnancy funds will more often affect pregnancy as a form of appreciation for them compared to pregnant women aged $<20$ years or $>30$ years. Pregnancy over the age of 30 years has a potential to be more complicated and risky. Pregnancy complications can occur at any age, and there will be an increase of pregnancy risks at the age of 30 years, such as premature, preeclampsia, and low birth weight babies. When pregnant women aged 40 years or older were compared with pregnant women aged 20-34 years, they were at a higher risk of having a fetus with chromosomal abnormalities. This age range is a risky age in pregnancy (Frederiksen et al., 2018). Women at the age of $<20$ years have the immature level of reproductive organs and weak uterine muscle. Risks at this pregnancy age include premature babies, bleeding and infection during childbirth, and abnormalities in fetal organ structures due to lack of nutritional intake received by pregnant women during pregnancy (Patel et al., 2016).

Pregnancy at a young age is also susceptible to genetic disorders, and it might be infected with viruses, such as rubella, toxo, and others. This condition is caused by imperfect antibodies and maturity of pregnant women's reproductive organs to anticipate the fetus from the threats of disease while in the womb (Arwani, Sekrawan and Kusnadi, 2013). At the age of $>35$ years, pregnant women have many hormonal changes, and the quality of the ovum in their womb was also no longer optimal. These impacts include fetus down syndrome or mental disorders in the process of fetus growth. In addition, there is a decrease of the contraction of uterine muscles to maintain and give birth babies. Pregnancy at too young or too old also has a psychological impact, such as being reluctant to check their pregnancy (Campbell et al., 2015).

In operational conditions, equity can be characterized as the non-attendance of difference wellbeing (the key social factors) that is efficiently connected to societal position. Age and culture may be seen to go hand in hand because older women have their own understanding of life and traditional beliefs that have both positive and negative impacts to antenatal attendance. The antenatal care may not be youth friendly, and the approach by health professionals to adolescent females may be discouraging (Mathe, 2017).

Table 2. Need and use for $5 \mathrm{~T}$ and $7 \mathrm{~T}$ based on age of pregnant women in the Primary Healthcare Center of Medokan Ayu.

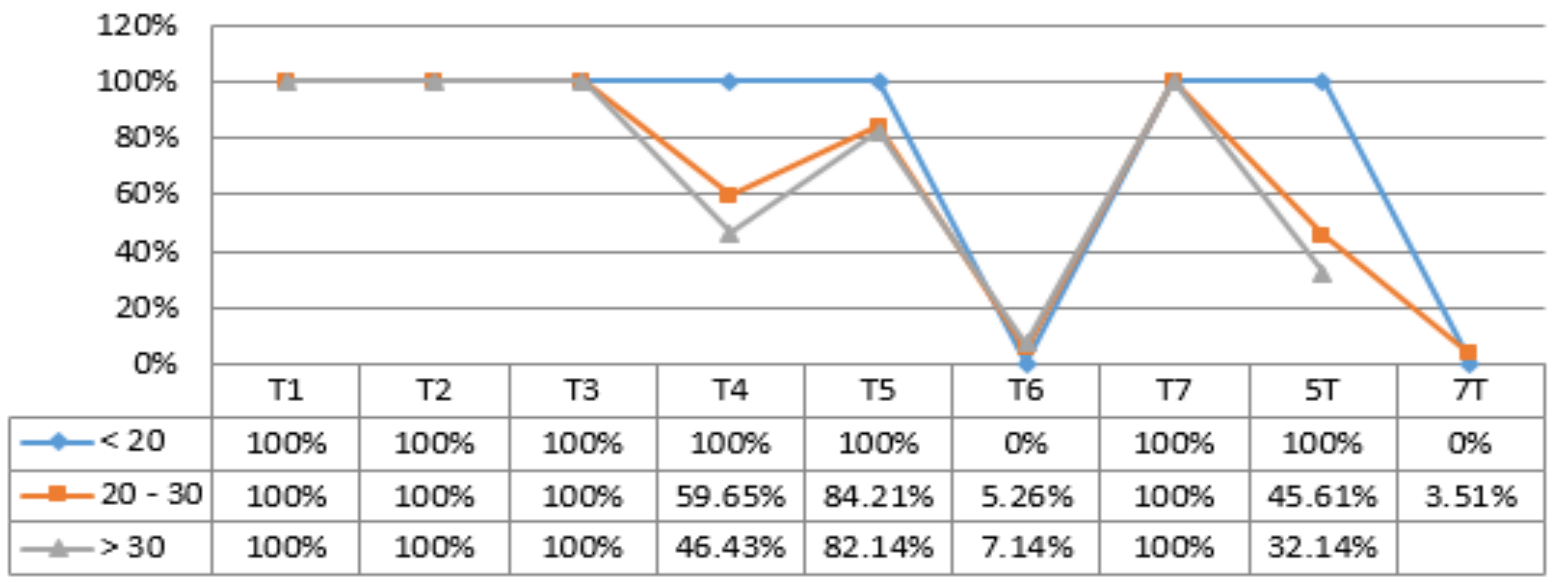

Table 2 shows that more complete $5 \mathrm{~T}$ by health professionals can be obtained by pregnant mothers at the age of $<20$ years while complete $7 T$ can be obtained by those at the age of 20 to 30 years. The data obtained showed that there were 38 respondents $(43.18 \%)$ who have received $5 \mathrm{~T}$, and 2 respondents have received $7 \mathrm{~T}$ out of 88 respondents $(2.27 \%)$. Meanwhile, complete $7 \mathrm{~T}$ was obtained more by the age of 20 to 30 years. Antenatal care provided according to standards greatly affects pregnant women's and their fetus health during pregnancy, childbirth and post-partum. The low number of respondents who received complete antenatal care can increase the maternal and neonatal morbidity and mortality (Saptarini and Suparmi, 2016).

Based on This research, incomplete 5T received by pregnant women was due to factors of immunization and less than 90 tablets administrated during pregnancy $(15.91 \%)$. Based on interview It occurred because there were pregnant women who did not know TT immunization and deliberately did not want to be injected. However, there were respondents who did not know the injection schedule. TT immunization programs for pregnant women in Indonesia are usually given twice, because they have not been fully immunized (5 times). Currently, neonatal tetanus is one of the main causes of infant mortality in Indonesia due to low coverage of antenatal care and TT immunization. Knowledge and attitudes that support pregnant women to behave might affect the use of immunization.

Infectious diseases and neonatal tetanus can actually be prevented with complete Tetanus Toxoid (TT) immunization for childbearing women and pregnant women. A woman who has complete TT immunization at 4-6 weeks interval is expected to have tetanus immunization for 3 years (Yunica, 2015). One of specific objectives of the immunization program is to eliminate Maternal and Neonatal 
Tetanus by increasing the coverage of immunization programs, especially Tetanus Toxoid (TT) immunization. The program of Indonesian maternal tetanus elimination showed that Indonesia adopted three immunization approaches to provide protection against tetanus for mothers and their babies, one of which was a short-term approach with a dose of Tetanus Toxoid (TT) for pregnant women given routine antenatal care, and a prospective TT dose the bride is given to women who want or are newly married. To maintain tetanus immunity at reproductive woman it is recommended to give 5 doses of Tetanus Toxoid immunization (TT) with a minimum of certain intervals (Manullang and Muliadi, 2012).

Tetanus Toxoid (TT) was administered to women of reproductive age (15-44 years) to protect them from tetanus and their newborn babies from neonatal tetanus. Neonatal tetanus is a grave disease caused by a bacterial pathogen transmitted during childbirth usually in an unhygienic condition. A woman needs a total of 5 TT doses for life long protection from tetanus, and all doses should be administered according to the WHO-recommended schedule (Islam et al., 2012)

Lack of knowledge in giving TT immunization at the time of antenatal care visit can affect the completeness of TT immunization during pregnancy. The low outcome of complete TT immunization coverage in pregnant women will reduce the effectiveness of immunization causing immunity and protecting infants and pregnant women from tetanus. Knowledge needs to be considered in terms of its effect on how pregnant women know about TT immunization and increase awareness of immunizations during pregnancy.

Factors that influence a person's knowledge are age, work, education and parity. The older, more mature, and stronger a person is, the more capable he is thinking and working. In terms of public trust, someone who is more mature will be more trusted than someone who is not mature enough. This idea is a result of experience and maturity of the soul that someone has received in his environment.

The role of health professionals in behavioural changes of pregnant women to carry out TT immunization can be applied by providing information about the benefits of TT immunization. Thus, knowledge will increase and generate awareness so that it will make people behave according to knowledge they own. The older, more knowledgeable a person is, he can change his behaviour to be better. Knowledge is one of the factors that influence the completeness of TT immunization status. From the results of the study, it was found that mothers with less knowledge in TT immunization had incomplete TT immunization status. Meanwhile, mothers with good knowledge obtained complete TT immunization status (Yuliana and Mursudarinah, 2017).

Baiee and Dhia (2015) in the city of Al-Hilla, assessed knowledge and practice of pregnant women regarding antenatal tetanus vaccine. Although most of them had heard of antenatal maternal tetanus vaccination, only a portion of them $(32.75 \%)$ had sufficient knowledge on this vaccine preventable disease. The majority of them obtained information about antenatal tetanus vaccination from the antenatal tetanus clinics. Only $40 \%$ of the pregnant women in this study received tetanus toxoid on schedule.

Another study conducted in Dhaka reported that more than two-thirds of respondents had knowledge of tetanus toxoid immunization before their reproductive period, but only half of them were truly vaccinated (Tanjida et al., 2009). Women who knew more about immunization had higher immunization rates. Women who acknowledge the importance of immunization had higher immunization rates.

Based on several studies above, knowledge mostly affects the completeness of TT immunization accomplished by pregnant women. The importance of knowledge can be used as a basis in seeing the condition of a pregnant woman for obtaining $5 \mathrm{~T}$. Pregnant women who had sufficient knowledge tend to complete TT immunization. When associated with maternal age, their mental development will be better, but at certain ages the mental development and the process of wanting to know something will be different compared to a relatively young age. Increasing age can also affect the ability to remember and receive knowledge.

Incomplete $7 \mathrm{~T}$ received by pregnant women due to incompleteness of $5 \mathrm{~T}$ and the absence of sexually transmitted disease tests for pregnant women. The standard implementation of the 7T antenatal care service standard begins with the complete 5T. Meanwhile, 2T namely the testing of section infectious diseases and counselling. The absence of one examination, such as the absence of an STI test, indicates that there is a service that does not meet the standards. It can be influenced by several factors, such as the lack of knowledge and attitude of midwives in carrying out STI tests for pregnancy (Parhusip, 2014).

Compared to women aged 16 to 24 years, women aged 35 to 40 years had roughly $32 \%$ lower likelihood being tested for chlamydia. Testing rates decreased as pregnant woman's age increased. The repetitive testing and follow-up testing for positive chlamydia were also re-examined (Fontenot and George, 2014). Healthcare providers are uniquely positioned to intervene in several ways. First, they have opportunities to enhance primary prevention of Sexually Transmitted Infection (STI) and education prior to pregnancy. They are often the first point of contact in primary, gynecologic and/or urgent care settings for STI and pregnancy tests. During the visits, it is important to provide sexual health education and resources to women and their partners (Blatt et al., 2012)

Equity in health implies that ideally everyone should have a fair opportunity to attain his or her full health potential and, that no one should be disadvantaged from achieving this potential, if it can be avoided. Equity in public health is that the primary determinant in the use of services should be the need for them and other factors such as income, race, place of residence and so forth should not play an important role in selecting who receives services and who does not (Aliy and Mariam, 2012). The acquisition standard of antenatal care, $5 \mathrm{~T}$ can be more fulfilled by pregnant women at the age of $<20$ 
years (100\%). The results of the study on $7 \mathrm{~T}$ done by pregnant women showed that 20 to 30 -year-old pregnant women were abler to get $7 \mathrm{~T}$. Whereas, pregnant women who were $<20$ years old and $>30$ years old did not get the complete 7T. According to Whitehead's theory, it can be concluded that pregnant women at the age of 20-30 years had the best level of equity in getting $7 \mathrm{~T}$.

The research not only looked at the incomplete immunization were received, but also the level of education. The level of education is one indicator measuring a person's social level. Someone with a higher level of education generally has more conducive lifestyle to healthy living than people with low levels of education. This can affect maternal awareness and knowledge about health. Safe and effective maternal vaccines will be useful if pregnant women decide to use them. Maternal knowledge, attitudes, and beliefs about vaccines are an integral part of the underlying mechanisms of vaccine hesitancy. Understanding these factors will allow public health practitioners to design more effective interventions (Williams et al., 2018).

Age is a unit of time that measures the existence period of an object or creature, both living and dead. The higher the level of maturity and strength is, the more mature a person will be in thinking and working. Thus, they will be motivated to get a pregnancy check and know the importance of antenatal care. First ANC visit during the first trimester of pregnancy: percentage of women aged 15-49 with a live birth in the survey reference period who underwent the first prenatal visit during the first trimester of pregnancy.

Antenatal care standards obtained by pregnant women who undergo $5 \mathrm{~T}$ are more acceptable to those aged $<20$ years old. Meanwhile, the antenatal care standards of $7 \mathrm{~T}$ is more acceptable to those aged 20-30 years old. Pregnant woman's age influences the acceptance of antenatal care standard. Women of the reproductive age need to recognize the importance of antenatal care in the community. Uplifting the socio-economic status and literacy rate of women is required to provide community-based education.

In terms of age, pregnant women at the age of 20-30 years can get 7T more since their level of education affects knowledge on antenatal care. The age of less than 20 years is usually dominated by pregnant women with elementary, middle and high school level. With a low level of education, it is possible that they do not know what to do during pregnancy.

Based on Table 3, women at the age of 20-30 years had more equity in receiving the $5 \mathrm{~T}$ antenatal care standard $(45.6 \%)$ and the $7 \mathrm{~T}$ standard equity. The acquisition of an antenatal care standard can be said to be fair if the service received is the same. The acquisition of antenatal care standards has not yet been obtained perfectly. Pregnant women at the age of 20-30 years complied with 5T and 7T antenatal care standards. Equity in health services is a justice in providing health services to two or more groups. Equity in health services can be interpreted as equal access to health services for the same needs, equal use for the same needs, and equal quality of service for all.
Table 3. Equity of Antenatal Care Standards in the Maternal Age Group in the Primary Healthcare Center of Medokan Ayu.

\begin{tabular}{ccc}
\hline \multirow{2}{*}{ Age } & \multicolumn{2}{c}{$\mathbf{5 T}$} \\
\cline { 2 - 3 } & Equity & Non equity \\
\hline$<20$ and $>30$ & 12 & 19 \\
years & $(38.7 \%)$ & $(61.3 \%)$ \\
$20-30$ years & 26 & 31 \\
& $(45.6 \%)$ & $(54.4 \%)$ \\
\hline \multirow{2}{*}{ Total } & 38 & 50 \\
& $(43.2 \%)$ & $(56.8 \%)$ \\
\hline
\end{tabular}

Most studies analyzed inequity in terms of income, socioeconomic status, literacy and age while inequity across administrative regions was seldom reported (Sanneving et al., 2015). Nevertheless, inequity of human resource distribution in maternal health system using complex equity metrics has been better described in comparison with the coverage indicators across dimensions (Himanshu and Källestål, 2017).

The results of the research showed that there were no differences in the acceptance standard of antenatal cares (5T and 7T) based on the age groups between $<20$ years, 20-30 years, and $>30$ years. Based on the results of the Chi-Square test, there were no differences in age variables and antenatal care standards performed in the Primary Healthcare Center of Medokan Ayu as one of Primary Healthcare Centers in Surabaya.

This study shows that the need for antenatal care standards can be fulfilled more for the age of $<20$ years and $>30$ years to avoid the high risk of maternal mortality and needs as well as equity based on the standards. What can be done to achieve better equity is by implementing antenatal care standards fitting to the community needs and providing equal treatments so that there is no inequity in the implementation of standard antenatal care.

\section{CONCLUSION}

The implementation of antenatal care standards has no difference between the ages of antenatal care standards. In this study, it was found that different age vulnerabilities had their own characteristic in getting equity. Age of 20-30 years could get complete $7 \mathrm{~T}$ services. It showed that women at this age with the least risk of pregnancy complications can get $7 \mathrm{~T}$ compared to other age groups. Healthcare providers need to improve the availability and quality of antenatal care, and awareness regarding antenatal care should be encouraged. Women in later reproductive period need to be aware of the risks that prevail them at any circumstances.

\section{CONFLICT OF INTEREST}

The authors declare that they have no conflict of interests.

\section{REFERENCES}

Aliy, J. and Mariam, D. H. (2012) 'Determinants of 
Equity in Utilization of Maternal Health Services in Butajira, Southern Ethiopia', Ethiopian Journal of Health Development, 900(13). Available at: https://www.ajol.info/index.php/ejhd/article/vie $\mathrm{w} / 116114$

Arwani, T., Sekrawan, N. and Kusnadi, D. (2013) 'Determinants of Antenatal Care Utilization at Public Health Center in Bandung City 2013', Konsentrasi Perencanaan Pembangunan Kesehatan, pp. 1-24. Available at: http://pustaka.unpad.ac.id/wpcontent/uploads/2014/03/tuni-arwiani130920120037.pdf.

Blanc, A. K., Winfrey, W. and Ross, J. (2013) 'New Findings for Maternal Mortality Age Patterns: Aggregated Results for 38 Countries', Public Library of Science, 8(4), pp. 1-9. doi: 10.1371/journal.pone.0059864.

Blatt, A. J. et al. (2012) 'Chlamydial and Gonococcal Testing During Pregnancy in the United States', American Journal of Obstetrics\&Gynecology. Elsevier Inc., 207(1), p. 55.e1--55.e8. 10.1016/j.ajog.2012.04.027.

Campbell, C. L. et al. (2015) 'Escape from Crossover Interference Increases with Maternal Age', Nature Communications. Nature Publishing Group, 6, pp. 1-7. doi: 10.1038/ncomms7260.

Frederiksen, L. et al. (2018) 'Risk of Adverse Pregnancy Outcomes at Advanced Maternal Age', Obstetrics \& Gynecology, 131(3), pp. 457-463. 10.1097/AOG.0000000000002504

Fontenot, H. B. and George, E. R. (2014) 'Sexually Transmitted Infections in Pregnancy', Nursing for Women's Health. Elsevier Masson SAS, 18(1), pp. 67-72. doi: 10.1111/1751486X.12095.

Himanshu, M. and Källestål, C. (2017) 'Regional Inequity in Complete Antenatal cares and Public Emergency Obstetric Care is Associated with Greater Burden of Maternal Deaths: Analysis from Consecutive District Level Facility Survey of Karnataka , India', Journal for Equity in Health. International Journal for Equity in Health, 16, pp. 1-11. doi: 10.1186/s12939-017-0573-3.

Islam, M. Z. et al. (2012) 'Tetanus Toxoid Vaccination Coverage Among Women of Reproductive Age: Experience From a Rural Community', Bangladesh Medical Journal, 41(1), pp. 1-5. Available https://www.banglajol.info/index.php/BMJ/arti cle/download/18780/13126\&prev=search.

Kapoyos, W. W. (2015) 'Hubungan Morning Briefing Dengan Tingkat Disiplin Perawat Di Ruang Interna RSUD Prof. Dr. H. Aloei Saboe Kota Gorontalo'. Universitas Negeri Gorontalo: Gorontalo.

Mathe, M. (2017) 'Socio-demographic factors affecting utilization of Antenatal care in Botswana', International Journal of Academic Research in Business and Social Sciences, 7(October), p. 481. doi: 10.6007/IJARBSS/v7i9/3343.

Manullang, E. V. and Muliadi, A. (2012) 'Tetanus
Maternal \& Neonatal', Buletin Jendela Data dan Informasi Kesehatan, September, pp. 139.

Patel, R. et al. (2016) 'Effect of Reproductive Ageing on Pregnant Mouse Uterus and Cervix .', The Journal of Physiology, pp. 1-44. doi: 10.1113/JP273350.

Sanneving, L. et al. (2015) 'Inequity in India: The Case of Maternal and Reproductive Health', Global Health Beyond, 1, pp. 1-32. doi: http://dx.doi.org/10.3402/gha.v6i0.19145.

Saptarini, I. and Suparmi (2016) 'Antenatal Care Service Utilization AND Completeness In Kebon Kelapa Village, Bogor 2014', Buletin Penelitian Kesehatan, 44, pp. 6-9.

Tanjida, S. et al. (2009) 'Status of Knowledge and Practice About Complete Tetanus Toxoid Immunization of Unmarried Female Students of a Public University in Dhaka', Bangladesh Journal of Medical Science, 8(4), pp. 102109.

doi: http://dx.doi.org/10.3329/bjms.v8i4.4707.

World Health Organization (2015) Trends in maternal mortality: 1990 to 2015. Switzerland. Available at: https://www.afro.who.int/sites/default/files/20 17-05/trends-in-maternal-mortality-1990-to2015.pdf.

Williams, A. L. et al. (2018) 'Maternal Vaccine Knowledge in Low and Middle Income Countries - and Why It Matters', Human Vaccines \& Immunotherapeutics. Taylor \& Francis, 00(00), pp. 1-4. doi: 10.1080/21645515.2018.1526589.

Yuliana, A. and Mursudarinah (2017) 'The Correlation Between Knowledge and Status of Tetanus Toxoid Immunization in 3rd trimester pregnant woman at PKD Bidan Desa Ngasinan Bulu Sukoharjo', Jurnal Kebidanan dan IImu Kesehatan, 4(2), pp. 1-13.

Yunica, J. A. (2015) 'Hubungan Antara Pengetahuan dan Umur dengan Kelengkapan Imunisasi Tetanus Toxoid ( TT ) pada Ibu Hamil di Desa Sungai Dua Kecamatan Rambutan Kabupaten Banyuasin Tahun 2014', Jurnal Kedokteran dan Kesehatan, 2(1), pp. 93-98. 